\title{
Book Review: Neanderthal Language: Demystifying the Linguistic Powers of Our Extinct Cousins
}

\author{
Petar Gabrić* \\ Institute for German Linguistics, Philipps University of Marburg, Marburg an der Lahn, Germany
}

Keywords: language evolution, Neanderthals, Paleolithic, Neanderthal language, cognitive archaeology

\section{A Book Review on}

\section{Neanderthal Language: Demystifying the Linguistic Powers of Our Extinct Cousins}

Rudolf Botha (Cambridge: Cambridge University Press), 2020, 209 pages, ISBN (hardback): 978-1$108-49132-7$

Recently, we have witnessed an explosion of studies and discussions claiming that Neanderthals engaged in a range of "symbolic" behaviors, including personal ornament use (Radovčić et al., 2015), funerary practices (Balzeau et al., 2020), visual arts (Hoffmann et al., 2018), body aesthetics (Roebroeks et al., 2012), etc. In Paleolithic archaeology, it has become mainstream to axiomatically infer from these putative behaviors that Neanderthals engaged in symbol use and that Neanderthals thus possessed some form of language. Rudolf Botha's bombastic title Neanderthal Language: Demystifying the Linguistic Powers of Our Extinct Cousins provides a detailed and very critical overview of the archaeological hypotheses and speculations about Neanderthal language.

Because language does not fossilize, eventual linguistic abilities of extinct hominins have to be inferred from indirect evidence. In the first two chapters, Botha introduces this "windows approach" to language evolution and proposes three conditions that should be met for window inferences to be sound. The inferences and conclusions must be pertinent-the phenomenon referred to (i.e., language) should be accurately identified, properly grounded in data about the window phenomenon, and warranted-the inferential step from the window phenomenon to language evolution should be justified. In chapters three to seven, Botha comprehensively reviews the current archaeological knowledge on the putatively "symbolic" Neanderthal behaviors, including putative jewelry, cave art, body aesthetics, and funerary practices. Botha masterfully demonstrates that there is no logical foundation to conclude that these putative behaviors reflect or constitute symbol use (in the Peircean or Saussurean sense), let alone language use. Botha (p. 54) asks: "What are the distinctive properties of symbols according to [these accounts]?" No adequate answer to this question is given in the archaeological literature. It is revealed that archaeologists typically axiomatically infer symbol use from the above-mentioned behaviors, e.g.: "[A]bstract or depictional representations and personal ornaments are the only unquestioned evidence of the emergence of symbolism." (d'Errico, 2009, p. 108). According to Botha, even if these behaviors were symbolic, the inferential step from these symbolic behaviors to language would be an arbitrary one.

Chapters eight to ten are devoted to stone-tool-related behaviors and hunting as examples of "non-symbolic" Neanderthal behaviors. Botha criticizes the literature on the relationship between Paleolithic stone tools and language evolution, arguing among others that stone tool production is very different from language. On the other hand, Botha somewhat surprisingly proposes that ambush hunting of large prey may indicate that Neanderthals possessed some form of language. Botha believes that such behaviors required close cooperation between individuals and thus communication-possibly, linguistic communication. Based on these data, Botha concludes his book by proposing that Neanderthals had a "simpler" form of language. 
Botha can be praised for his critical review and evaluation of the archaeological studies of "symbolic" Neanderthal behaviors through which he demonstrates that the association between the putatively "symbolic" behaviors and actual linguistic symbol use is completely arbitrary, i.e., not based on any linguistic ontology. Botha is not only critical but offers a tentative framework for the evaluation of the existing as well as future window inferences in language evolution.

On the other hand, Botha's account of the eventual relationship between stone-toolmaking-related behaviors and the linguistic status in Neanderthals is less convincing as well as misleading. Most problematically, Botha pays practically no attention to specifically Neanderthal stone tools but discusses older forms of Paleolithic stone tools. Botha rejects the putative hypothesis that stone toolmaking and language are so similar that the presence of stone toolmaking indicates the presence of language, citing Stout and his colleagues among others. However, Stout is not a proponent of such a hypothesis, but of a hypothesis that there are cognitive processes which underlie both stone-toolrelated and linguistic behaviors, and that language thus might rely on processes and networks which were reused from processes and networks "originally" involved in stone-tool-related behaviors, e.g.: "[E]arly stone tool making [possibly] favored adaptations later incorporated into an evolving language capacity" (Stout and Chaminade, 2007, p. 1098; cf. Gabrić et al., 2018). Further, to support his assertion that stone toolmaking is not "recursive" (without defining what recursion is), Botha cites Berwick and Chomsky (2016) adding that the two are not sure whether the knapping procedure can be depicted as a "syntactic tree." Whether some people think that something can or cannot be depicted as a tree should not guide conclusions about whether a phenomenon is "recursive" or not.

Botha's conclusions are also somewhat obscure. Botha (p. 156) proposes that Neanderthals possessed "a form of language with basic units resembling arbitrary linguistic signs" which "lacked the complex grammatical properties of full modern language." It is unclear what Botha wants to say with this conclusion. What kind of language does not contain linguistic signs (but "units resembling" them)? That seems paradoxical. What are "complex grammatical properties" (and what are simple ones?) and why aren't they needed for ambush hunting of large prey? What are "full modern languages" and on which properties is the gradation of "language modernity" based? Did Neanderthal languages have syntactic constituents, word classes, transitivity, morphological processes, prosody, a large repertoire of consonants and vowels,

\section{REFERENCES}

Balzeau, A., Turq, A., Talamo, S., Daujeard, C., Guérin, G., Welker, F., et al. (2020). Pluridisciplinary evidence for burial for the La Ferrassie 8 Neandertal child. Sci. Rep. 10:21230. doi: 10.1038/s41598-02077611-z

Berwick, R. C., and Chomsky, N. (2016). Why Only Us: Language and Evolution. Cambridge, MA; London: MIT Press. doi: 10.7551/mitpress/9780262034241. 001.0001

Botha, R. (2009). "Theoretical underpinnings of inferences about language evolution: the syntax used at Blombos Cave," in The Cradle of Language, eds R. etc.? Why does Botha not discuss previous and linguistically more detailed accounts of Neanderthal language (Progovac, 2016)? Unfortunately, Botha's window inference fails at (at least) one of his own principles for sound inferences-it is impertinent, i.e., the linguistic phenomenon in question is not adequately identified. Furthermore, his conclusions are based on a very brief review of studies on Neanderthal hunting, studies tentatively suggesting an association between the FOXP2 variants in Neanderthals and language and studies suggesting that specific, yet very broadly demarcated, brain areas are smaller in size or volume in Neanderthals compared to modern humans. Firstly, the FOXP2 hypothesis is not characterized in adequate detail (cf. Kuhlwilm, 2018), while a number of other topics in Neanderthal genetics have emerged throughout the years apart from the endlessly discussed FOXP2 (Murphy and BenítezBurraco, 2018; Silvert et al., 2019; Villanea and Schraiber, 2019; Taskent et al., 2020; Reinscheid et al., 2021). Secondly, to suggest that the smaller size or volume of particular brain areas in Neanderthals compared to modern humans is indicative of both the presence and absence of specific linguistic features in Neanderthals (p. 156) is highly controversial at best. Thus, Botha's conclusions also appear ungrounded and unwarranted.

In conclusion, Botha's (2020) evaluation of the "symbolic" hypotheses about Neanderthal language is of great value, given that previous criticisms of such axiomatic thinking have not received adequate attention (Botha, 2009, 2010, 2012, 2015; Garofoli, 2014; Garofoli and Iliopoulos, 2019). In fact, chapters three to seven should be mandatory reading for anyone interested in studying Neanderthal behavior, both experts and non-experts. Further, Botha's proposal that specific hunting behaviors may be an indicator of linguistic communication in Neanderthals will hopefully induce future discussions on this hypothesis. On the other hand, Botha's account of the relationship between Neanderthal stone tools and language may be somewhat problematic, while his conclusions lack substance.

\section{AUTHOR CONTRIBUTIONS}

PG was solely responsible for this manuscript.

\section{ACKNOWLEDGMENTS}

The content of the manuscript has previously appeared online as a preprint (Gabrić, 2021).
Botha and C. Knight (Cambridge: Oxford University Press), 93-111. Available online at: http://hdl.handle.net/10019.1/44890

Botha, R. (2010). On the soundness of inferring modern language from symbolic behaviour. Camb. Archaeol. J. 20, 345-356. doi: 10.1017/S0959774310000454

Botha, R. (2012). "Inferring modern language from ancient objects," in The Oxford Handbook of Language Evolution, eds K. R. Gibson, and M. Tallerman (New York, NY: Oxford University Press), 303-312. doi: 10.1093/oxfordhb/9780199541119.013.0030

Botha, R. (2015). Teaching and learning subsistence skills: did premodern hominins use language to do it? Camb. Archaeol. J. 25, 901-908. doi: $10.1017 /$ S0959774315000335 
Botha, R. (2020). Neanderthal Language: Demystifying the Linguistic Powers of Our Extinct Cousins. Cambridge: Cambridge University Press. doi: $10.1017 / 9781108868167$

d'Errico, F. (2009). "The archaeology of early religious practices: a plea for a hypothesis-testing approach," in Becoming Human: Innovation in Prehistoric Material and Spiritual Culture, eds C. Renfrew and I. Morley (Cambridge: Cambridge University Press), 104-122.

Gabrić, P. (2021). Book review: "Neanderthal Language: Demystifying the Linguistic Powers of Our Extinct Cousins" by Rudolf Botha. PsyArXiv. doi: 10.31234/osf.io/zs37p

Gabrić, P., Banda, M., and Karavanić, I. (2018). "Palaeolithic toolmaking and the evolution of cognition and language," in Cognitive Science, eds T. Strle and O. Markič (Ljubljan: Institut “Jožef Stefan”), 12-16. doi: 10.5281/zenodo.4674332

Garofoli, D. (2014). Do early body ornaments prove cognitive modernity? A critical analysis from situated cognition. Phenomenol. Cogn. Sci. 14, 803-825. doi: 10.1007/s11097-014-9356-0

Garofoli, D., and Iliopoulos, A. (2019). Replacing epiphenomenalism: a pluralistic enactive take on the metaplasticity of early body ornamentation. Philos. Technol. 32, 215-242. doi: 10.1007/s13347-017-0296-9

Hoffmann, D. L., Standish, C. D., García-Diez, M., Pettitt, P. B., Milton, J. A., Zilhão, J., et al. (2018). U-Th dating of carbonate crusts reveals Neandertal origin of Iberian cave art. Science 359, 912-915. doi: 10.1126/science.aap7778

Kuhlwilm, M. (2018). The evolution of FOXP2 in the light of admixture. Curr. Opin. Behav. Sci. 21, 120-126. doi: 10.1016/j.cobeha.2018.04.006

Murphy, E., and Benítez-Burraco, A. (2018). Paleo-oscillomics: inferring aspects of Neanderthal language abilities from gene regulation of neural oscillations. J. Anthropol. Sci. 96, 111-124. doi: 10.4436/JASS.96010

Progovac, L. (2016). A gradualist scenario for language evolution: precise linguistic reconstruction of early human (and Neandertal) grammars. Front. Psychol. 7:1714. doi: 10.3389/fpsyg.2016.01714

Radovčić, D., Sršen, A. O., Radovčić, J., and Frayer, D. W. (2015). Evidence for Neandertal jewelry: modified white-tailed eagle claws at Krapina. PLoS ONE 10:e0119802. doi: 10.1371/journal.pone.0119802
Reinscheid, R. K., Mafessoni, F., Lüttjohann, A., Jüngling, K., Pape, H.C., and Schulz, S. (2021). Neandertal introgression and accumulation of hypomorphic mutations in the neuropeptide S (NPS) system promote attenuated functionality. Peptides 138:170506. doi: 10.1016/j.peptides.2021. 170506

Roebroeks, W., Sier, M. J., Nielsen, T. K., De Loecker, D., Pares, J. M., Arps, C. E. S., et al. (2012). Use of red ochre by early Neandertals. Proc. Natl. Acad. Sci. U.S.A. 109, 1889-1894. doi: 10.1073/pnas.1112261109

Silvert, M., Quintana-Murci, L., and Rotival, M. (2019). Impact and evolutionary determinants of Neanderthal introgression on transcriptional and post-transcriptional regulation. Am. J. Hum. Genet. 104, 1241-1250. doi: 10.1016/j.ajhg.2019.04.016

Stout, D., and Chaminade, T. (2007). The evolutionary neuroscience of tool making. Neuropsychologia 45, 1091-1100. doi: 10.1016/j.neuropsychologia.2006.09.014

Taskent, O., Lin, Y. L., Patramanis, I., Pavlidis, P., and Gokcumen, O. (2020). Analysis of haplotypic variation and deletion polymorphisms point to multiple archaic introgression events, including from Altai Neanderthal lineage. Genetics 215, 497-509. doi: 10.1534/genetics.120.303167

Villanea, F. A., and Schraiber, J. G. (2019). Multiple episodes of interbreeding between Neanderthal and modern humans. Nat. Ecol. Evol. 3, 39-44. doi: 10.1038/s41559-018-0735-8

Conflict of Interest: The author declares that the research was conducted in the absence of any commercial or financial relationships that could be construed as a potential conflict of interest.

Copyright $\odot 2021$ Gabrić. This is an open-access article distributed under the terms of the Creative Commons Attribution License (CC BY). The use, distribution or reproduction in other forums is permitted, provided the original author(s) and the copyright owner(s) are credited and that the original publication in this journal is cited, in accordance with accepted academic practice. No use, distribution or reproduction is permitted which does not comply with these terms. 